Bronisława Woźniczka-Paruzel, prof. dr hab.

Uniwersytet Mikołaja Kopernika w Toruniu Instytut Informacji Naukowej i Bibliologii bwp@umk.pl

\title{
Rola multimediów w komunikacji głuchych dzieci i nastolatków oraz w ich dostępie do informacji i czytelnictwa
}

\section{The role of multimedia in communication of deaf children and teenagers and in their access to information and reading}

Bronisława Woźniczka-Paruzel - pracuje jako profesor w Instytucie Informacji Naukowej i Bibliologii Uniwersytetu Mikołaja Kopernika w Toruniu. Jej dorobek naukowy obejmuje ponad 100 publikacji z zakresu bibliologii. Kilkadziesiąt z nich poświęconych jest biblioterapii, bajkoterapii, czytelnictwu dzieci i praktykom czytelniczym osób z niepełnosprawnościami, w tym głuchych od urodzenia. Ostatnio interesuje się alternatywnymi materiałami czytelniczymi dla ludzi z uszkodzonym słuchem oraz rolą multimediów w komunikacji głuchych dzieci i nastolatków.

Wybrane publikacje:

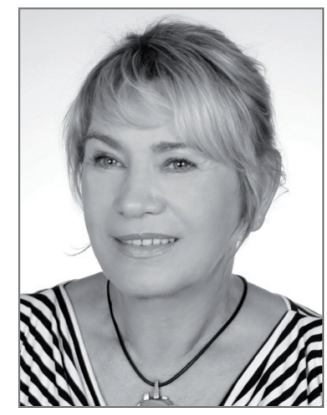

- Are our libraries really open to all? Access to information and new technology for people with disabilities in Poland [Czy nasze biblioteki są rzeczywiście otwarte dla wszystkich?] [in:] Open 2001: Knowledge, information and democracy in the Open Society: role of library and information Sector. Proceedings of the International BOBCATSSS Symposium on Library and Information Science, Vilnius, 2001

- Biblioterapia $i$ czytelnictwo $w$ środowiskach osób niepetnosprawnych [Bibliotherapy and reading in environments of people with disabilities], 2001, [red.]

- Biblioterapia i jej przemiany na tle rozwoju teoretycznych koncepcji światowych [Bibliotherapy and its transformation on the background of the development of theoretical concepts of the world] [w:] Woźniczka-Paruzel B., Biblioterapia i czytelnictwo w środowiskach osób niepetnosprawnych, 2001.

Bronistawa Woźniczka-Paruzel - works as a full professor at the Institute of Information Science and Book Studies at Nicolaus Copernicus University in Torun. Her academic achievements are more than 100 publications in the field of bibliology. Dozens of them are dedicated bibliotherapy, fairytale-therapy, children's reading, and reading practices of persons with disabilities, including born deaf. Recently she is interested in alternative reading materials for people with hearing impairment and in the role of multimedia in communication of the deaf children and teenagers. 


\section{Wprowadzenie}

Termin multimedia zwykle rozumiany jest jako połączenie różnych form przekazu informacji, które stanowi kombinację mediów elektronicznych: filmu, obrazów, dźwięków i tekstu, często umożliwiającą odbiór interaktywny. Chociaż termin ten doczekał się różnorodnych definicji, wydaje się, że w rozważaniach nad komunikacją ludzi głuchych od urodzenia, a zwłaszcza młodej ich generacji, całkowicie wystarczy to potoczne jego rozumienie. Pamiętać jednak należy, że tradycyjne pojmowanie multimediów jako zbioru wielu urządzeń do przekazu treści, powoli staje się nieaktualne. Cyfrowy świat doprowadza do integracji poszczególnych mediów, co wskazuje na traktowanie multimediów nie jako zbioru odrębnych mediów lecz jako całości. Przez multimedia można więc rozumieć zarówno tradycyjne środki - przedmioty umożliwiające różnorodny przekaz informacji, np. telewizor czy magnetowid, ale i komputer ze wszystkimi elementami składającymi się na jego multimedialność, tj. z drukarką, skanerem, kartą muzyczną, kartą graficzną, głośnikami, mikrofonem, kamerą video lub cyfrową internetową, z kartą telewizyjną, cyfrowym aparatem fotograficznym, modemem, czytnikiem płyt kompaktowych, czytnikiem dyskietek, nagrywarką, a także z dostępem do sieci. To także oprogramowanie pozwalające na poszukiwanie i odbieranie różnorodnych komunikatów oraz ich tworzenie, zapisywanie, czy przetwarzanie (Multimedia-podstawowe pojęcia [online]).

Mając na uwadze powyższe ustalenia stwierdzić można, że dzięki rozwojowi technologii informacyjnych, a zwłaszcza komputera z Internetem, umożliwiających zarówno wykorzystanie, jak tworzenie multimediów, młode pokolenia niesłyszących, dla których mową macierzystą jest język migowy, wkracza w świat jeszcze do niedawna dostępny wyłącznie dla „mieszkańców świata dźwięków”, zaś młodzi ludzie z niedosłuchem czują się w tym świecie coraz pewniej, przy czym mogą przy tej okazji rozwijać mowę foniczną.

Połączenie różnych mediów w synkretyczne całości, uwzględniające specyficzne możliwości odbiorcze osób głuchych, stwarza im nowe możliwości dostępu do informacji, edukacji, kultury, sztuki i rozrywki, przełamując zarazem bariery izolacji, związane z komunikowaniem się za pomocą wizualno-przestrzennego języka migowego, a także integrując tych, którzy się nim posługują. Multimedia mogą zatem pełnić szereg niezwykle istotnych funkcji społecznych, a przy tym obecnie najważniejsze są dla dzieci i młodzieży, tj. dla tych, którzy stanowią pokolenie e-tubylców. Właśnie oni chcą oraz potrafią z nich korzystać. Do nich również adresowane są różne rodzaje form multimedialnych, które pozwalają wprowadzić ich w świat książki, czytania i czytelnictwa, zarówno w ich własnym języku, jak w języku fonicznym. Czas zatem je przedstawić, tym bardziej, że nie doczekały się one ujęć funkcjonalnych, co stanowi podstawowy cel tego artykułu. Ujęcia 
te określają rolę multimediów w życiu „mieszkańców świata ciszy”, zwłaszcza ich młodej generacji. Na początek jednak nieco historii.

\section{Adaptacje mediów dla niesłyszących w dobie przedinternetowej}

Jeszcze przed rewolucją internetową, w okresie prymatu telewizji, pojawiły się próby dostosowania różnorakich informacji do możliwości percepcyjnych osób z uszkodzonym słuchem. Znaczna część z nich przetrwała do dziś, tyle że uległy udoskonaleniu oraz szerszemu upowszechnieniu. Do najpopularniejszych należą:

1) standardowe nagrania z osobami mówiącymi, w których u dołu ekranu pojawia się okienko z tłumaczem języka migowego,

2) dolne napisy w programach telewizyjnych i emitowanych w telewizji filmach, dostępne poprzez teletekst,

3) filmy zawierające w napisach, oprócz dialogów, informacje o dźwiękach towarzyszących akcji, sposobie mówienia i reakcjach bohaterów, których nie widać na ekranie (tzw. deskrypcja),

4) nagrania przedstawiające osoby mówiące migami, z głosem lektora lub napisami (Woźniczka-Paruzel B. 2014, s. 361-362).

Oczywiście, z upływem czasu, w telewizji zaczęto emitować coraz więcej programów tłumaczonych na język migowy, do tego doszły filmy edukacyjne, upowszechniające problemy osób niesłyszących oraz seriale i krótkie filmy fabularne z niesłyszącymi aktorami, posługującymi się najczęściej językiem migowym, które dostępne są również dla słyszących dzięki napisom lub głosom lektorów. Chociaż wskazane formy adaptacji przekazów telewizyjnych i filmowych do potrzeb niesłyszących rozwijają się w dalszym ciągu, wraz z upowszechnieniem się Internetu i dostępnym dzięki niemu programom oraz technologiom, pojawiły się nowe, których rozwój w naszym kraju nastąpił przede wszystkim jako rezultat aktywności samej społeczności osób głuchych, identyfikujących się z własnym językiem i ze związaną z nim kulturą. Ich aktywność doprowadziła m.in. do prawnego usankcjonowania tego języka w Ustawie o jezzyku migowym i innych środkach komunikowania się (2011). Równolegle do tego rozwijały się prace nad jego rozpowszechnieniem, w czym niebagatelną rolę odegrał słownik języka migowego, opracowany w postaci multimedialnej.

\section{Stownik Polskiego Języka Migowego i jego odmiany}

Opracowanie słownika wideo polskiego języka migowego, dostępnego również w kilku wersjach w Internecie, stało się niezwykle ważnym wydarzeniem w rozwoju komunikacji wizualno-przestrzennej, gdzie istotne są nie tylko znaki manualne, określające poszczególne słowa, litery lub liczby, ale również ruchy wykonywane 
głową i tułowiem, z mimicznymi znakami wyrażającymi emocje włącznie. Słownik ten umożliwia odtwarzanie w dowolnym tempie klipów wideo z wybranymi przez użytkownika znakami języka migowego (oczywiście, wraz z ich ruchem!), klatka po klatce, w przód i wstecz, pozwala na odtwarzanie haseł na małym ekranie lub w trybie pełnoekranowym, są tu także zmieniające się zdjęcia układu dłoni, które można powiększyć oraz opisy i komentarze do każdego znaku. Można również odtworzyć i powtarzać słowa przypisane poszczególnym znakom, które odczytywane są przez lektora, grupować pojęcia we własne zestawy oraz wyszukiwać poszczególne znaki. Dodać należy, że jakość nagrań jest bardzo wysoka. Przykładowa strona SPJM widoczna jest na ilustracji 1, co pozwala zobaczyć możliwości, jakie oferuje omawiany Słownik.

\section{Il. 1. Słownik Polskiego Języka Migowego}

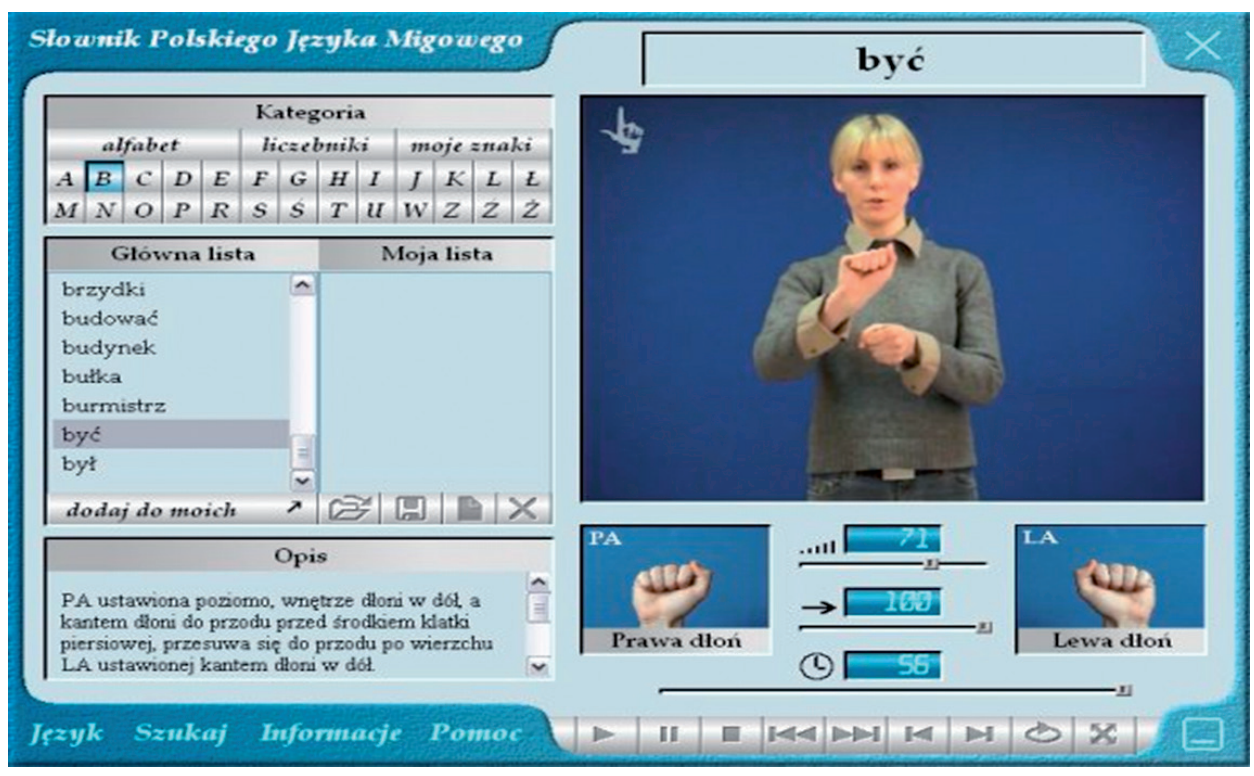

Źródło: Stownik Polskiego Języka Migowego [online], [dostęp: 21.08.2014], dostępny w Internecie: <http://www.spjm.webd.pl>

Stownik Polskiego Jezzyka Migowego, wydany przez Polski Związek Głuchych (PZG) w roku 2005, multimedialnie opracowany został przez Piotra Gutkowskiego przy współpracy pracowników Łódzkiego Oddziału Polskiego Związku Głuchych. Był w ciągu ostatnich lat rozwijany i udoskonalany. Jego skrócone wersje demonstracyjne są bezpłatne i dostępne po zalogowaniu się, natomiast wersje rozszerzone trzeba zakupić (Stownik Polskiego Jezzyka Migowego [online]). 
Język migowy można poznawać i/lub utrwalać także poprzez Komputerowy Stownik Języka Migowego - aplikację, która dostępna jest i reklamowana w sieci pod wieloma adresami. Obejmuje ona słownik zawierający 530 filmów prezentujących znaki języka migowego oraz 4 atrakcyjne gry logopedyczne dla dzieci (np. Patrzę i mówię - wyrazy, czy Patrzę i mówię - głoski). Jego wersję demonstracyjną można pobrać m.in. z serwisu PCWorld.pl, gdzie również doczekał się krótkiego omówienia (Komputerowy Stownik Języka Migowego [online]).

Jest jeszcze Stownik języka migowego on-line opracowany przez pracowników portalu Migam.pl (o portalu - szerzej w dalszych częściach rozważań). Tutaj wystarczy stwierdzić, że jest to słownik bardzo udany, przejrzyście ułożony i świetnie pokazujący sposoby migania znaków przez sfilmowanych lektorów, czemu towarzyszy także artykulacja foniczna każdego wybranego hasła. Układ haseł, w podziale na kategorie, wskazuje ilustracja 2.

\section{Il. 2. Zrzut ekranu strony otwierającej Stownik języka migowego portalu Migam.pl}

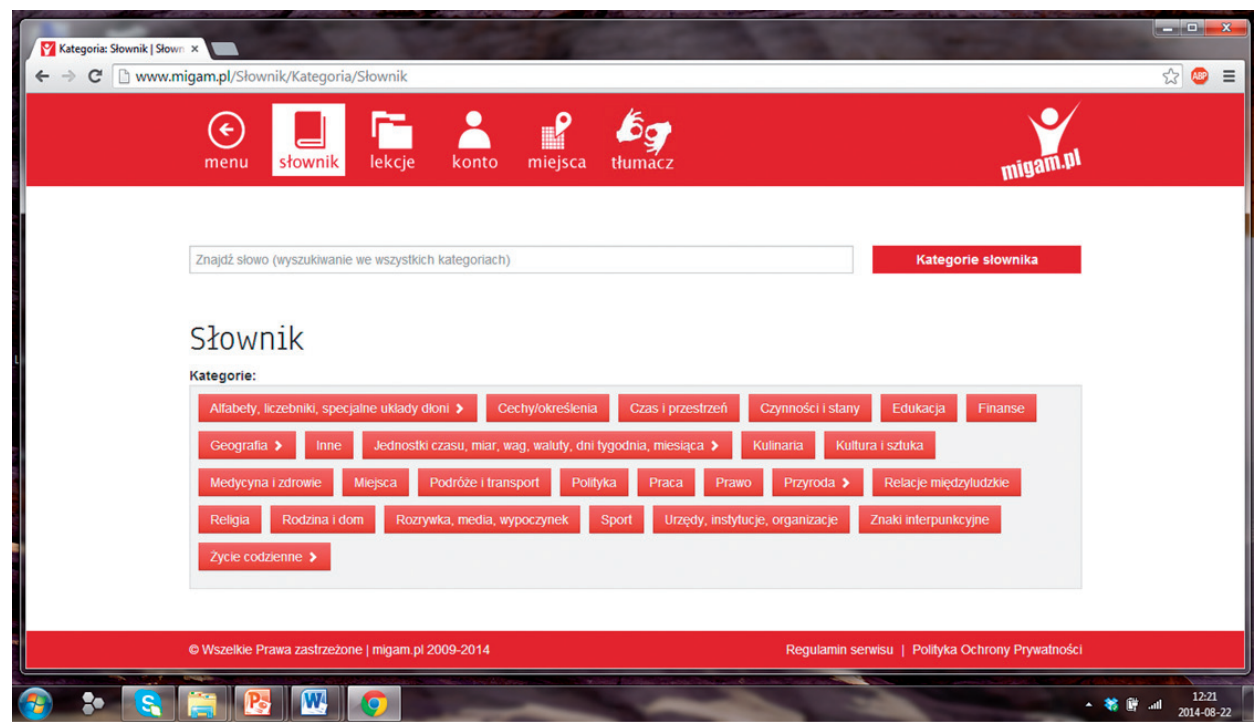

Źródło: Stownik [online], [dostęp: 20.08.2014], dostępny w Internecie: <http://www.migam.pl/ Słownik/Kategoria/Słownik>

Warto podkreślić, że poszczególne rodzaje i wersje słowników języka migowego służyć mogą zarówno osobom słyszącym, które chcą opanować podstawy języka migowego, jak i ludziom niesłyszącym, którzy w ten sposób uczą się znaków skodyfikowanych, poszerzając swój zasób leksykalny, a tym samym - doskonaląc swój język macierzysty. Jednocześnie, w przypadku opanowania podstaw języka fonicznego, uczonego przecież w szkołach, użytkownicy z uszkodzonym słuchem, 
zwłaszcza niedosłyszący, mogą ćwiczyć artykulację wybranych znaków, ponieważ mogą powtarzać ją za lektorem. Jest to szczególnie ważne przede wszystkim dla dzieci i młodzieży, jako że młode pokolenie coraz bardziej otwiera się na świat zewnętrzny i częściej niż osoby starsze wychodzi poza hermetyczne środowisko „mieszkańców świata ciszy”.

W tym miejscu wypada dopowiedzieć, że dzieci głuche od urodzenia, a zwłaszcza te, których matka lub ojciec są niesłyszący, od najwcześniejszych miesięcy życia poznają otaczający ich świat za pomocą gestów i pozawerbalnych środków komunikacji. Uczą się języka migowego w sposób równie naturalny, jak dzieci słyszące uczą się języka fonicznego od słyszących rodziców. Język migowy, doskonalony z czasem w kontaktach z niesłyszącymi rówieśnikami i osobami dorosłymi spoza kręgu rodzinnego, staje się dla nich wyznacznikiem odmienności kulturowej, nośnikiem wartości i zasad obowiązujących w społeczności Głuchych (tak, przez duże G!), z którą się identyfikują (Sak M. 2012, s. 16).

Dzieci głuche, objęte obowiązkiem szkolnym, uczą się również fonicznego języka narodowego, na ogół w ośrodkach szkolno-wychowawczych dla nich przeznaczonych. W założeniu zatem powinny być dwujęzyczne, do czego zresztą dąży się obecnie niemal na całym świecie. Problem w tym, że w polskich szkołach raczej nie mogą przyswajać mowy fonicznej oraz wiedzy za pośrednictwem macierzystego polskiego języka migowego (PJM), ponieważ nauczyciele pomocniczo posługują się tzw. językiem miganym, oficjalnie nazwanym systemem językowo-migowym (SJM), prawie w ogóle niezrozumiałym dla uczniów. SJM ma składnię i gramatykę języka polskiego, zaś jego zasób leksykalny tworzą pojęcia ideograficzne zaczerpnięte z PJM. Ponieważ język polski jest dla niesłyszących dzieci językiem obcym, a struktura gramatyczna ich macierzystego języka migowego - całkowicie inna (jest to język pozycyjny), przy braku autokontroli słuchowej nie są one w stanie opanować polskiego, także w jego formie pisanej (Woźniczka-Paruzel B. 2013, s. 161-163). Pomocne być tu mogą właśnie multimedialne słowniki PJM, ale również odpowiednie gry edukacyjne i logopedyczne, które coraz częściej dostępne są w sieci.

\section{Multimedialne gry edukacyjne i logopedyczne}

Obecnie jest ich coraz więcej, w postaci pakietów programów dostępnych w Internecie lub poprzez e-księgarnie. Bardzo interesujący jest pakiet programów do diagnozy i terapii logopedycznej firmy Young Digital Planet. W skład pakietu wchodzą różnego rodzaju programy i gry (m.in. Logo-gry, Mówiące obrazki), a także Aplikacja logopedy. Można pobrać darmowe wersje demonstracyjne, po wcześniejszej rejestracji poprzez zakładkę Logopedia serwisu wrocławskiej firmy Dobreprogramy.pl. Seria Logopedia od ponad dwudziestu lat wspomaga m.in. te- 
rapeutów i rodziców dzieci z uszkodzonym słuchem (Logopedia [online]). Kształtuje kompetencje językowe dzieci w zabawny i ciekawy sposób, wprowadza do języka fonicznego, również w jego formie pisanej, co powinno ich przygotować do samodzielnego czytania oraz ułatwić im wejście do tradycyjnie utrwalonej literatury dla dzieci. Trudno byłoby przedstawić całą ofertę Logopedii, stąd też omówione zostały wyłącznie programy komputerowe Mówiace obrazki oraz Alfabet. Zabawy literami i gtoskami, dostępne również w księgarniach internetowych w postaci CD.

Mówiące obrazki to program, który stanowi połączenie idei kolorowych plansz, animacji i naturalnych odgłosów otaczającego świata, tworzących razem uniwersalne narzędzie wspomagające terapię logopedyczną dzieci z uszkodzonym narządem słuchu. $Z$ jego pomocą uczą się one rozróżniania dźwięków, ponieważ do każdej ilustracji przypisany jest naturalny dźwięk, dzięki czemu mali odbiorcy jednocześnie go słyszą (można znacznie wzmocnić fonię) oraz widzą źródło jego pochodzenia lub sytuację, w której powstaje (por. Mówiące obrazki - Program komputerowy do terapii dzieci... [online]).

\section{Il. 3. Przykładowe obrazki programu Mówiące obrazki, wskazujące na jego możliwości}

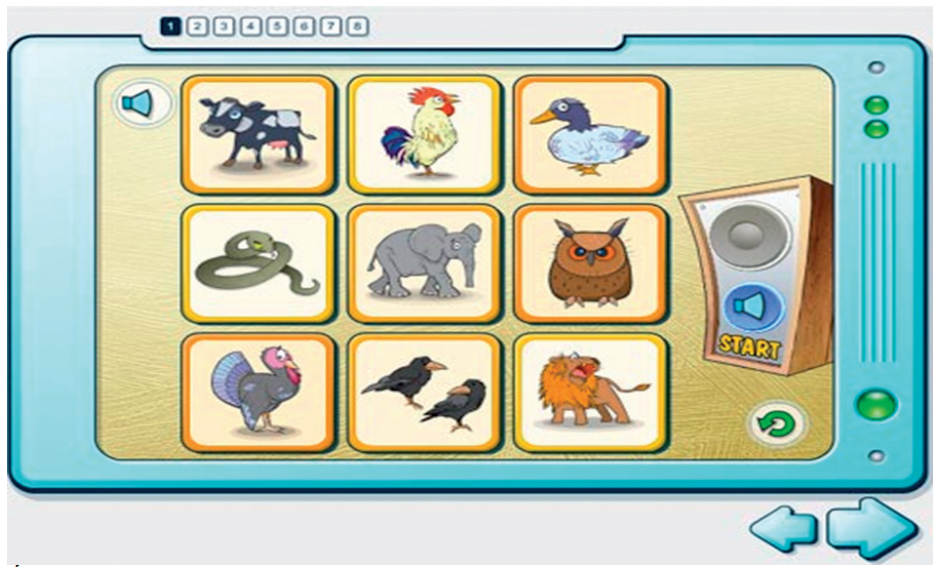

Źródło: Mówiace obrazki [online], [dostęp: 20.08.2014], dostępny w Internecie: <http://www.3kropki.pl/p/4/2/0/edusensus_logopedia_ mowiace_obrazki.php>

Na całość Mówiących obrazków składa się ponad 100 interaktywnych ilustracji i animacji. Dźwięk uruchamia się po kliknięciu ilustracji, która animuje się w zabawny sposób, co zachęca dzieci do wielokrotnego odtwarzania dźwięku i wykonywania ćwiczeń. Dodatkowo wszystkie obrazki mogą zostać wydrukowane 
w wersji czarno-białej i przekazane dziecku do pokolorowania. Atutem programu są przystępnie podane informacje o narządzie słuchu, z omówieniem jego rozwoju i zaburzeń oraz możliwości jego stymulacji, czemu towarzyszą propozycje prostych ćwiczeń grafomotorycznych oraz wesołe sprawdziany na rozumienie tekstu, kierowane do dzieci umiejących już czytać i pisać. Program ułatwia także opanowanie różnych pojęć językowych, m.in. stosunków przestrzennych (nauka rozumienia przyimków), antonimów, nazw kolorów, nazw instrumentów muzycznych, pojazdów, zwierząt, zjawisk przyrody. Jest to zatem również świetna pomoc dla dzieci uczących się mówić. Dodać przy tym należy, że wszystkie umiejętności nabyte przez małych użytkowników mogą zostać sprawdzone na stronach testowych zawierających ćwiczenia, które są jednocześnie doskonałym pretekstem do zabawy (kolorowanki, gry pamięciowe, łączenie w pary i inne) (por. opis: eduSensus Logopedia. Mówiace obrazki 2.0 [online]).

Z kolei Alfabet. Zabawy literami i gtoskami. Ćwiczenia percepcji stuchowej wprowadza w elementarny świat alfabetu (liter, głosek oraz wyrazów), uczy podstaw czytania i pisania, kształtuje gotowość do nauki czytania i pisania, pozwala ćwiczyć elementarne zdolności językowe, trenuje również znajomość pisowni. Mali użytkownicy uczą się nowych słów w sposób naturalny - najpierw poznają ich brzmienie i kojarzą je z obrazami, ćwiczą także percepcję słuchową, porównując słowa o podobnym brzmieniu. Ćwiczenia rozwijające analizator słuchowy połączone są więc z ćwiczeniami rozwijającymi analizator wzrokowy (zob. opis: Alfabet. Zabawy literami i gtoskami... [online]).

Omawiany program wydany został na płycie CD i dostępny jest w kilku e-księgarniach. Łączy w sobie fascynującą multimedialną zabawę z nauką liter i poznawaniem alfabetu. Obejmuje 16 rozdziałów, zawierających mnóstwo ciekawych i przyjaznych dzieciom ćwiczeń. Umożliwiają one poznanie i zapamiętanie kształtu liter, słów z nich zbudowanych, ich pisownię, a także poprawną wymowę. Z kolei jego 9 podprogramów (Linia, Piłka, Poziom, Samolot, Papuga, Armata, Szum, Rybka, Tenis), zapewnia wizualne sprzężenie zwrotne pomiędzy wybranymi parametrami głosu a obrazem na ekranie komputera. Towarzyszą temu ćwiczenia rytmiki mowy, modulacji głosu i intonacji oraz redukcji zaburzeń fazy wydechowej, przy jednoczesnej wizualizacji głosu dziecka i możliwości ujrzenia jej na ekranie monitora. Całość zachęca do wykonywania różnorodnych ćwiczeń dzięki atrakcyjnej grafice, animacjom i różnorodnym wzmocnieniom pozytywnym.

Przy omawianiu multimediów dla dzieci z niedosłuchem, warto też wspomnieć o logo-grach dla nich przeznaczonych. Można je znaleźć we wspomnianym pakiecie Logopedii, ale i w sieci (są wśród nich darmowe), inne można kupić w niektórych księgarniach. Przykładowo wymienić tu można Logo-Gry 2.0. Są zestawem składającym się z 26 gier, stanowiących atrakcyjny element wspomagający terapię logopedyczną dzieci z zaburzeniami słuchu i mowy, ale przydatne są również dla 
dzieci z autyzmem, mutyzmem i opóźnionym rozwojem umysłowym (Logo-Gry 2.02014 [online]).

Logo-gry mają charakter edukacyjno-rozrywkowy. Stymulują rozwój mowy za pomocą wielu bodźców wizualnych i dźwiękowych, pozwalają niedosłyszącym dzieciom poznać możliwości swojego głosu, bawią, a jednocześnie umożliwiają efektywną terapię, przy czym - co niezwykle istotne - dają użytkownikom poczucie sprawstwa, co zachęca je do samodzielnej aktywności, a to może wyzwalać kreatywność. Tworzone są odrębnie również dla nastolatków, w tym - na użytek szkolny, co zamienia naukę w interaktywną zabawę.

Skoro już o ćwiczeniach logopedycznych mowa, warto wspomnieć o tym, że mogą być one prowadzone także online dzięki zespołowi polskich naukowców programistów, którzy podjęli prace badawcze nad rozpoznawaniem mowy cią̧łej i wykorzystaniu tego w praktyce. Zbudowali oni SkryBota, który jest kompletnym systemem rozpoznawania i dekodowania mowy do tekstu. Na SkryBota składa się dekoder, modele akustyczne i językowe oraz zestaw narzędzi, którymi udoskonalono cały program (Nasze rozpoznawanie mowy: SkryBot.pl [online]). W ramach prac powstał Toker - pierwszy w Polsce interaktywny, multimedialny program logopedyczny, wspomagający rozwój mowy zarówno dzieci w wieku przedszkolnym i szkolnym, jak i dorosłych z afazją, np. po udarach. Może stanowić ogromne wsparcie terapii logopedycznych w środowisku domowym, co w odniesieniu do dzieci z uszkodzonym słuchem ma ogromne znaczenie (Platforma Toker [online]).

W innej sytuacji niż dzieci z niedosłuchem są te, które urodziły się głuche. Wiele z nich nie jest w stanie opanować języka fonicznego, a zatem - korzystać ze standardowo wydawanych publikacji czarnodrukowych i informacji mówionej. Wyrastają na ludzi żyjących w świecie ciszy, dla których jedynym środkiem komunikacji jest język migowy. Nie znaczy to jednak, że są wyłączeni ze świata informacji i pozbawieni możliwości uczestniczenia w różnych formach życia kulturalnego, obcowania ze sztuką itp. Znów tutaj przychodzą z pomocą multimedia, a zwłaszcza portale multimedialne, najczęściej tworzone przez ludzi głuchych lub dla nich przeznaczone. Nawiasem mówiąc, na ogół twórcami i najczęstszymi użytkownikami tych portali są ludzie młodzi.

\section{Niesłyszący w sieci - wybrane portale - charakterystyka ogólna}

Jest ich już sporo, więc nie sposób przedstawić ich wszystkich, dlatego do opisu wybrane zostały te, które wydają się najciekawsze, a zarazem nie tylko pełnią ważne funkcje informacyjne, ale również upowszechniają kulturę społeczności Głuchych (w tym - język migowy) oraz dążą do włączenia cyfrowego i społecznego ludzi z uszkodzonym analizatorem słuchu. Zacząć wypada od powstałej w $2001 \mathrm{r}$. strony www.glusi.pl. 
Witryna ta początkowo miała stanowić portal społeczności niesłyszących i taką funkcję pełniła do 2006 r., kiedy została zawieszona. Po pięciu latach została wznowiona, w nowym układzie i nowej szacie graficznej. Jej twórcy tak określają jej cel:

Celem witryny jest utworzenie miejsca, w którym gromadzone będą wszelkie informacje dotyczace Glgtuchych i stabostyszacych. Ma to być rodzaj magazynu informacji, zarówno aktualnych, jak i archiwalnych, szczególnie dotyczących spraw dziejacych się $w$ Polsce. Respektując prawa autorskie, nie zamieszczamy petnych kopii materiatów, a jedynie linki prowadzace do oryginalnych artykutów, audycji, reportaży, wypowiedzi w PJM. Będziemy też zamieszczać oryginalne artykuty nie publikowane wczé́niej. $W$ części strony prowadzonej $w$ języku polskim będziemy zamieszczać transkrypcje wszelkich materiatów audiowizualnych emitowanych $w$ radio $i$ telewizji dotyczacych Glgtuchych i stabostyszacych (Glusi.pl [online]).

Podkreślić należy, że zgodnie z założeniami twórców portalu, jego adresatami są zarówno osoby głuche i słabosłyszące, jak słyszące, zainteresowane problemami społeczności ludzi z uszkodzonym analizatorem słuchu, przy czym ma on spełniać wymogi dostępności dla wszystkich. Znajduje to wyraz w jego układzie, oferującym wersję tekstową w języku polskim oraz wersję w PJM i innych językach migowych (wraz z filmami opatrzonymi deskrypcją), czemu towarzyszy forum w polskim języku migowym, udokumentowane ilustracją 4 .

\section{Il. 4. Strona startowa portalu Glusi.pl}

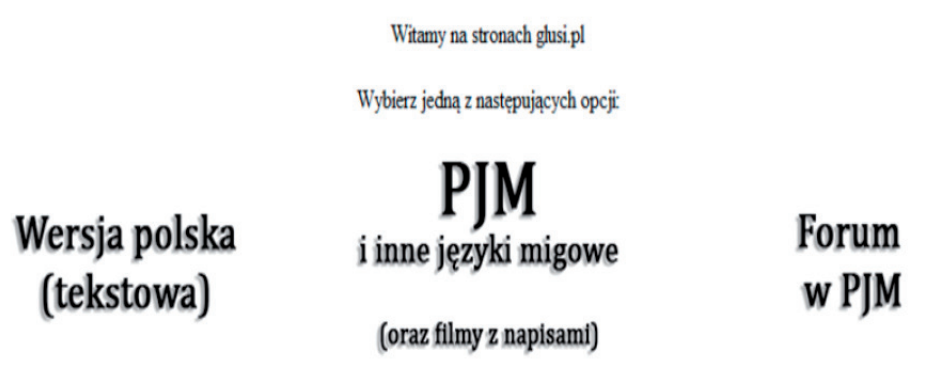

Polska wersja serwisu - teksty $\quad \underline{\text { Katalog flimów w PJMi innych iezykach migowych }} \quad$ Fonum w PJM

Źródło: Glusi.pl [online], [dostęp: 20.08.2014], dostępny w Internecie :<http://www.glusi.pl> 
Najciekawsze części omawianego portalu to te, które dostępne są w języku migowym, ponieważ tam właśnie wykorzystane zostały przekazy o charakterze multimedialnym. W części PJM zgromadzone są filmy, głównie wideo (uporządkowane kategoriami), przy czym sfilmowanym przekazom w języku migowym (PJM, czasem SJM lub w amerykańskim języku migowym (ASL)) najczęściej towarzyszą napisy w języku polskim, niekiedy słychać głos lektora. Natomiast Forum obejmuje wyłącznie nagrania osób posługujących się PJM (również podzielone na kategorie tematyczne, przy czym zdecydowana większość filmów zamieszczona została przez samych uczestników dyskusji). Dominują tutaj ludzie młodzi, należący już do e-generacji. Ciekawe jest też na Forum okienko, w którym osoby włączające się do dyskusji mogą się przedstawiać.

Bez wątpienia omawiany portal po ostatnich zmianach stał się bardzo funkcjonalny, dobrze służąc zarówno społeczności Głuchych, jak i osobom niedosłyszącym, dzięki wersji tekstowej zaś korzystać z niego mogą również użytkownicy słyszący, którzy nie władają językiem migowym, a są zainteresowani prywatnie bądź zawodowo „mieszkańcami świata ciszy” i ich problemami.

Do ciekawych należy także serwis Glusi.com.pl, który pojawił się w roku 2011, jednakże od pewnego czasu zniknął z dotychczasowego adresu, chociaż nadal pozostała po nim informacja w You Tube: (Zapraszamy: www.glusi.com.pl [online]) oraz na stronie Spoteczność Gtuchych w portalu Facebook (Spoteczność Gtuchych [online]). Być może jest teraz w przebudowie lub został zawieszony, lecz mimo to warto spojrzeć na jedną z jego archiwalnych stron, wskazująca, jak bogata jest (była?) jego oferta, obejmująca m.in. szereg nagrań filmików w języku migowym, poświęconych najbardziej istotnym sprawom osób niesłyszących, filmów o charakterze instruktażowym, np. pokazującym, jak załatwiać różne sprawy w urzędach, jak założyć konto na You Tube, czy jak zamieścić na tej platformie własny film (Il. 5).

Osoby niesłyszące i słabosłyszące korzystają z możliwości, jakie daje Internet, często samodzielnie tworząc własne serwisy. Wskazuje na to witryna Organizacji Niesłyszących - Słabosłyszących Internautów (ONSI). Dynamika działania autorów tego serwisu i głębokie zaangażowanie w problematykę osób $\mathrm{z}$ wadą słuchu zachęcają do przeglądania jego stron.

ONSI jest inicjatywą społeczną. Tworzą ją ludzie związani z Serwisem internetowym ONSI oraz Stowarzyszeniem ONSI. Stowarzyszenie poprzez swój portal zapewnia osobom głuchym i niedosłyszącym nowoczesne możliwości komunikacyjne i dostęp do najważniejszych informacji, w tym również tych, które związane są edukacją, kulturą, sztuką i rozrywką. Publikuje on informacje ważne nie tylko dla nich, ale i dla tłumaczy języka migowego oraz wszystkich osób związanych ze społecznością Głuchych. Poprzez Chat daje możliwość spotkań osób niesłyszących, a także ich słyszących przyjaciół w formie dyskusji na żywo, zaś dzięki Forum 


\section{Il. 5. Archiwalna strona portalu Glusi.com.pl}

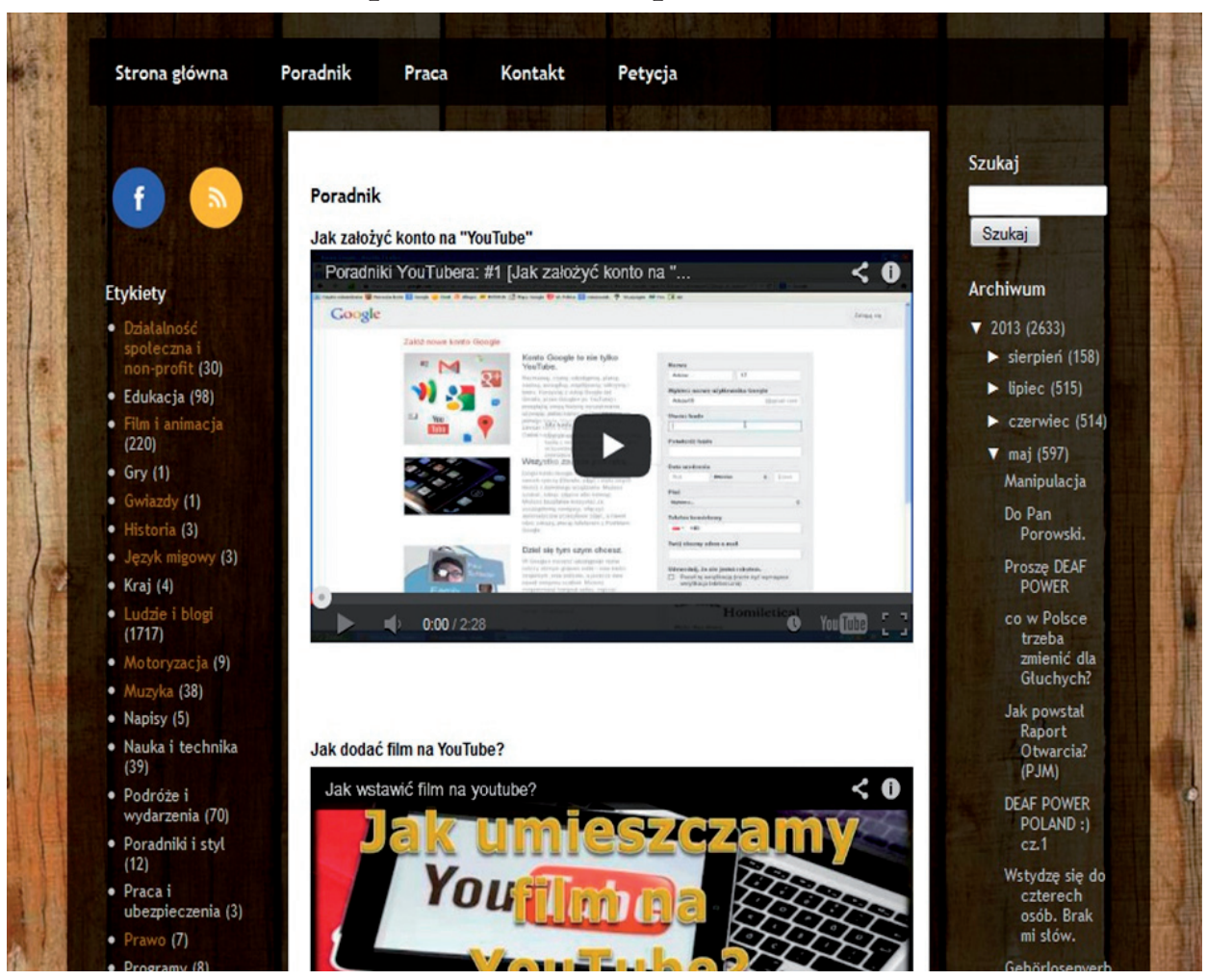

Źródło: Gtusi [online], [dostęp: 29.12.2012], dostępny w Internecie: <http://www.glusi.com.pl> (adres obecnie nieaktywny).

użytkownicy mogą się połączyć ze stroną Deaf Poland, stanowiącą ogólnopolskie Forum dyskusyjne osób z wada stuchu (Deaf Poland... [online]). Ponadto, poprzez Ogtoszenia, użytkownicy portalu mogą załatwiać różnego rodzaju sprawy związane z życiem codziennym. Najciekawszą jednak częścią omawianego portalu jest telewizja internetowa, która codziennie, od poniedziałku do piątku, przekazuje w języku migowym najważniejsze newsy z kraju i ze świata. Ponieważ o telewizji dla niesłyszących będzie jeszcze mowa później, tutaj wystarczy stwierdzić, że ONSI przydatny może być we wszystkich sferach życia osób z uszkodzonym słuchem.

Jedną z najciekawszych inicjatyw podjętych przez osoby z uszkodzonym słuchem wspólnie ze słyszącymi, jest Spółka z o.o. Migam.pl i jej projekty. Powstała w 2010 r., podejmując prace nad systemem tłumaczeń online. W rok później jej założyciel nawiązał współpracę z Towarzystwem Osób Niesłyszących TON oraz Towarzystwem Tłumaczy i Wykładowców Języka Migowego GEST, zyskując także inwestorów zewnętrznych, co przyniosło początek prac nad omówionym 


\section{Il. 6. Zrzut ekranu startowego ONSI}

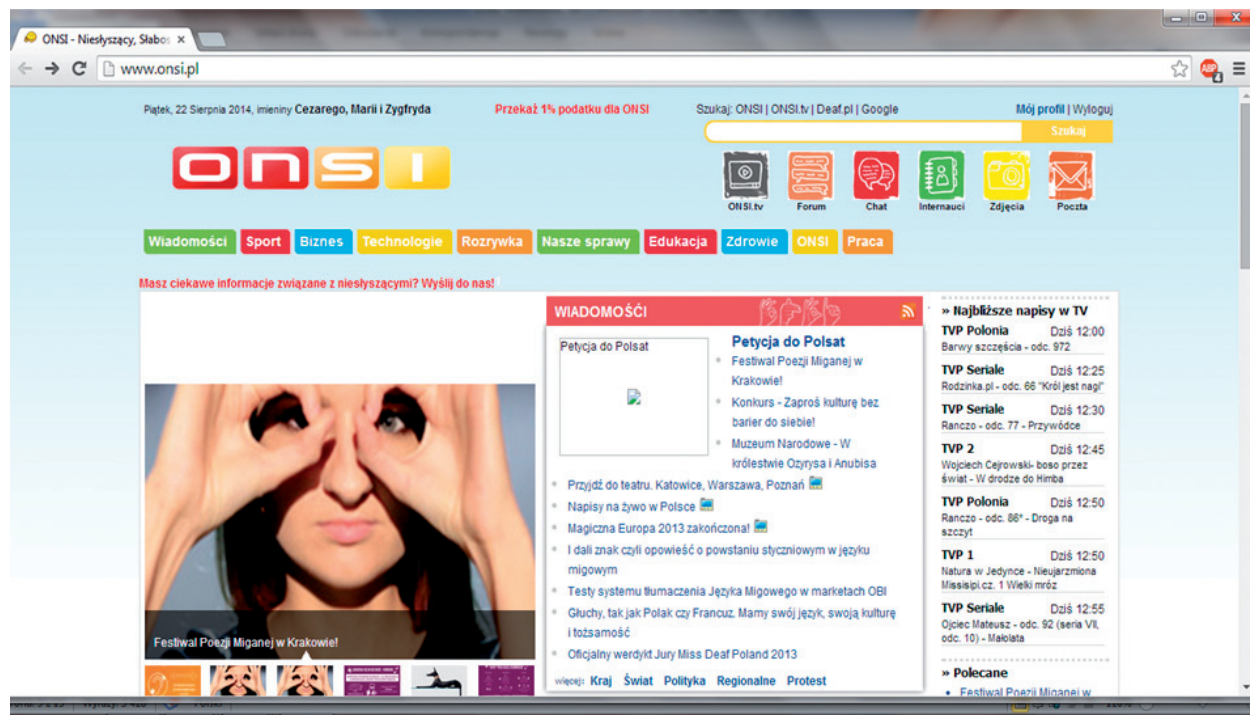

Źródło: Organizacja niestyszących... [online], [dostęp: 22.08.2014], dostępny w Internecie: $<$ www.onsi.pl>

już Stownikiem Języka Migowego online. Z czasem współpraca objęła Państwowy Fundusz Rehabilitacji Osób Niepełnosprawnych (PFRON), ale i Microsoft, projekt się rozrastał i przybywało współpracowników oraz sukcesów (np. 1 miejsce dla Migam na StartUpHeros). Co istotne, zaczęły się również prace badawcze nad systemem rozpoznawania znaków języka migowego z wykorzystaniem kamer Kinect i kolejne nagrody (m.in. spółka została laureatem Aulery2013). Po wygranej Virgin Academy i innych sukcesach oraz pobycie członków w Dolinie Krzemowej, Migam.pl nawiązało kontakty zagraniczne, rozwijając swoje projekty we współpracy z USA, Indiami i Ukrainą (Migam [online]). Można się zatem spodziewać następnych nowości, które w dużej mierze ułatwią społeczności Głuchych zarówno życie codzienne, jak i dostęp do wszystkich profitów związanych ze światem wiedzy i informacji.

Chociaż w ostatnim okresie powstało więcej portali dla niesłyszących, aby nie nużyć, tę część wywodów należałoby zakończyć omówieniem najmłodszego. Jest to Gtuchy Świat - Portal osób gtuchych i ich przyjaciót. Stworzony został 10 stycznia 2014 r. przez Stowarzyszenie Głuchy Świat, które powstało na bazie istniejącego od 2012 r. Klubu Sportowego Niesłyszących GS KONIN (Stowarzyszenie Gtuchy Świat [online]). Przejrzyście skonstruowany, zachęca do odwiedzin, informując o rozmaitych działaniach niesłyszących oraz aktywności na ich rzecz. Ich stronę główną prezentuje ilustracja 7 . 


\section{Il. 7. Zrzut ekranu strony głównej portalu Głuchy Świat}

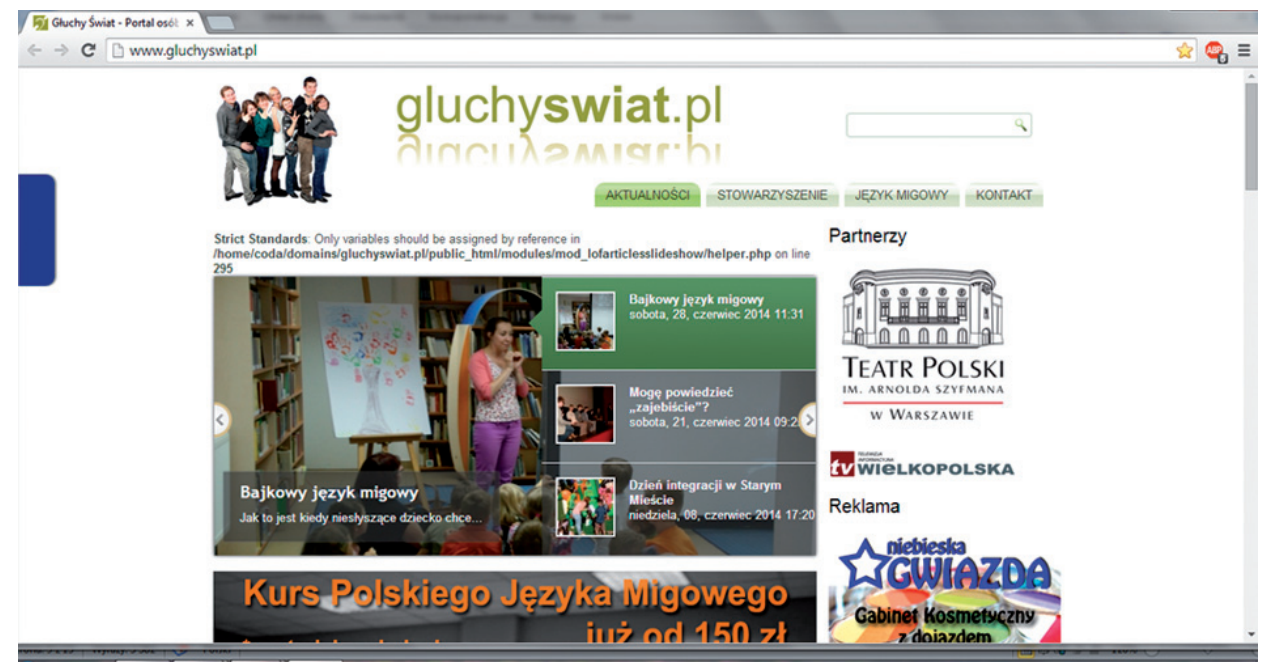

Źródło: Stowarzyszenie Gtuchy Świat [online], [dostęp: 22.08.2014], dostępny w Internecie: $<$ http://www.gluchyswiat.pl>

Omówione tutaj portale mają ambicje ogarnięcia wszystkich sfer funkcjonowania człowieka z uszkodzonym słuchem we współczesnym świecie, poświęcając także wiele uwagi problemom dzieci i młodzieży, spotkaniom z bajkami, zajęciom z książką, szansom edukacyjnym młodego pokolenia oraz ich włączaniu cyfrowemu. Zwykle też zaopatrzone są w zakładki, obliczone na dzieci i wczesnych nastolatków. Ich rodzice mogą znaleźć tam informacje o multimediach przydatnych dla swoich pociech, a młodzi internauci - wyszukać te, które interesują ich najbardziej, w dostępnej im formie multimedialnej. Są jednak również programy i witryny multimedialne obliczone przede wszystkim na rozwój ich uczestnictwa w kulturze, sztuce i rozrywce, zarówno biernego - w charakterze odbiorców, jak czynnego - jako twórców.

\section{Multimedia w kulturze, sztuce i rozrywce osób z uszkodzonym stuchem}

Tę część rozważań wypadałoby zacząć od oferty kierowanej do dzieci, by później przejść do możliwości, jakie multimedia stwarzają młodzieży i dorosłym, zwłaszcza tzw. młodym dorosłym, którzy nie chcą odbiegać od słyszących rówieśników, zanurzonych w rzeczywistości cyfrowej.

Nie ma chyba wątpliwości, że dla dzieci najważniejsze są bajki i baśnie. O ich pozytywnym wpływie na nie napisano już setki prac, więc nie trzeba o tym nikogo 
przekonywać. Głuche dzieci nie mają jednak do nich dostępu, ani gdy czytają je im rodzice, ani gdy oglądają je w nagraniach standardowych, w tym telewizyjnych, bo wówczas podstawą percepcji jest słyszenie i rozumienie dialogów. Dlatego też już w 1994 r. w polskiej telewizji pojawiły się Bajki nie tylko dla dzieci gtuchych, w reżyserii Marty Boruń - wówczas nauczycielki w Ośrodku Szkolno-Wychowawczym dla Dzieci Niesłyszących w Szczecinie. W rolach aktorów wystąpili uczniowie Ośrodka, grający w języku migowym (Woźniczka-Paruzel B. 2014, s. 362-363).

Cykl obejmujący początkowo 6 odcinków, zrealizowany został dla redakcji „W Świecie Ciszy”, ale w związku z dużą oglądalnością, został przeniesiony do „Redakcji dziecięcej” TVP 2. W tej redakcji powstał cykl 32 bajek, również w wersji dla dzieci słyszących, w której tekst bajki, „wymigiwanej” przez małych aktorów czyta lektor. W roku 1997 część bajek (8) została wydana przez Ministerstwo Edukacji Narodowej i Sportu w ramach pakietów multimedialnych Powszechnej Wideoteki Edukacyjnej - na kasetach VHS. Były to: Stowik, Król jest nagi, Kot w butach, Czerwony kapturek, Królewna Śnieżka, Księżniczka na ziarnku grochu, Kuma śmierć, a zatem klasyka bajkowej literatury dziecięcej. Jednak pozostałe bajki nie doczekały się odrębnych wydań i ponownych emisji w telewizji, ale dzięki dziennikarzom „Głosu Szczecińskiego” omówione i umieszczone zostały w 2011 r. na jednej ze stron internetowego serwisu tego czasopisma (Folkman A. 2014 [online]). Można do nich dotrzeć również poprzez ich stronę na Facebooku, gdzie - sądząc po liczbie „lajków” i odsłon - do dziś cieszą małych odbiorców (Bajki nie tylko dla dzieci gtuchych [online]).

Dla młodzieży z uszkodzonym słuchem i przy jej udziale zrealizowany został w 2009 r. pierwszy w Europie serial zagrany wyłącznie w języku migowym pt. Zobaczyć ciszę. Serial ten obejmuje 5 odcinków, z których każdy trwa 10 minut. Opowiada o losach wrażliwej nastolatki, która pomimo głuchoty marzy, aby zostać aktorką. Wrodzona inteligencja, upór i dyscyplina pomogą jej przezwyciężyć wszystkie trudności i osiągnąc upragniony cel. Jak piszą realizatorzy (producentem jest Adam Cieplak, a reżyserem Marek Brodzki, znany chociażby z realizacji „Wiedźmina”), poszczególne odcinki poruszają szereg ważnych tematów, jak np. utrudnione z powodu głuchoty kontakty z rówieśnikami, niełatwe relacje rodzinne, miłość do przypadkowo poznanego chłopaka i wreszcie dążenie do spełnienia marzeń (Zobaczyć cisze [online]).

Aktorzy nie używają słów, lecz posługują się językiem migowym, osoby słyszące zaś mogą śledzić akcję dzięki zamieszczonym napisom, co w środowisku nastolatków odgrywa bardzo ważną rolę integracyjną. Świadczy o tym fakt, że serial, który dostępny jest m.in. na filmowym kanale TV Głuchych w You Tube, poprzez portal stworzony specjalnie dla Zobaczyć ciszę, obejrzało tysiące internautów, zarówno głuchych, jak słyszących, zamieszczając zarazem wiele pozytywnych komentarzy. 
Zresztą do oglądania zachęca już sam zwiastun, o czym można się przekonać, wchodząc na Zobaczyć cisze - zapowiedź ([online]).

W kontekście dostępu do szeroko pojmowanej kultury i sztuki oraz ich współtworzenia przez niesłyszących i słabosłyszących, na szczególną uwagę zasługują te strony internetowe, które koncentrują się na różnych formach ich aktywności w tym właśnie zakresie. Informacje o nich upowszechniane są przez wspomnianą już kilkakrotnie Telewizję Głuchych, istniejącą od lipca 2013 r., w ramach portalu Głusi 24.Info. Nie brakuje tam różnorakich informacji w postaci nagrań osób migających je w PJM. Czasem też są to standardowe relacje filmowe w języku fonicznym, którym towarzyszy lektorski przekład na język migowy (w okienku z prawej strony ekranu), a niekiedy również napisy. Można się stąd dowiedzieć np. o edukacji najmłodszych, w tym - o elementarzu w wersji dla niesłyszących uczniów, który trafił do ich rąk w roku szkolnym 2014/15, z pewnością ułatwiając im naukę, o wydarzeniach kulturalnych, adresowanych zwłaszcza do ludzi młodych, czy akcjach podejmowanych przez społeczność Głuchych itp. Słowem: portal ten, wraz z Telewizją Głuchych, nie tylko dostarcza informacji dostosowanych do specyficznych możliwości odbiorczych docelowych adresatów, ale również zachęca ich do uczestnictwa w kulturze i/lub współtworzenia jej, oferując także rozrywkę oraz dyskusje nad rozmaitymi problemami związanymi z ich życiem „W świecie dźwięków”, wcześniej dla nich trudno dostępnym lub niedostępnym w ogóle. Trudno zatem nie docenić tej portalowej formy multimedialnej.

\section{Il. 8. Zrzut strony portalu Głusi24.info}

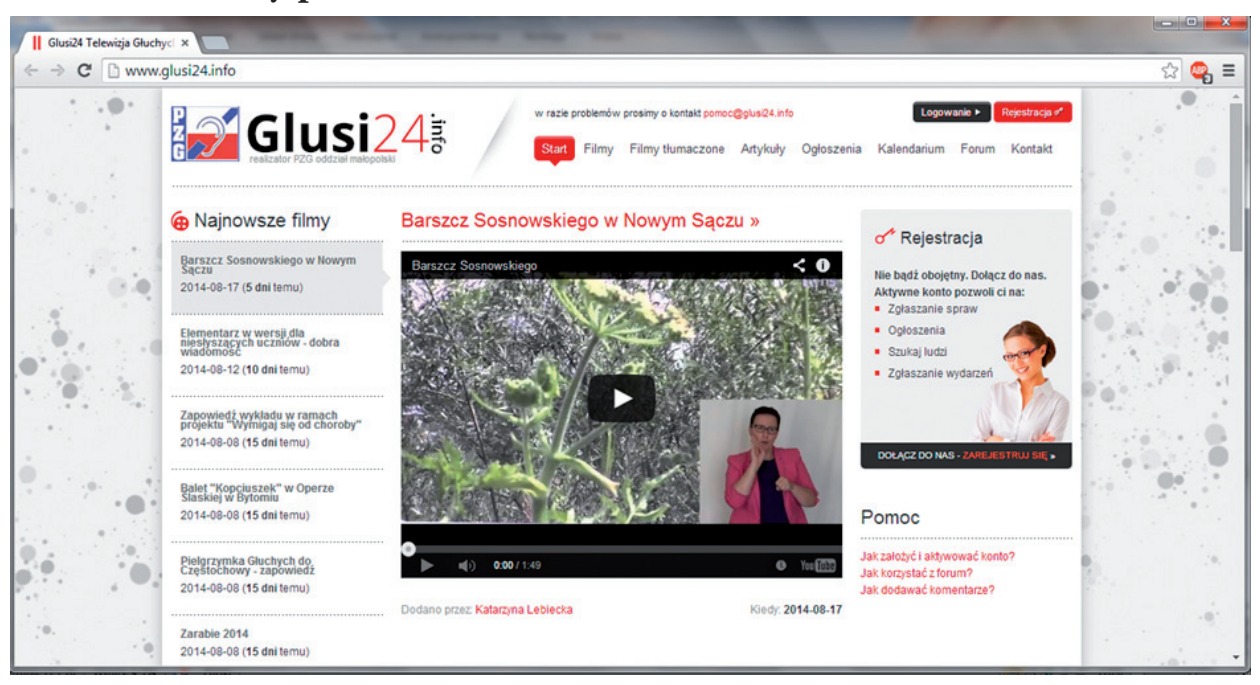

Źródło: Glusi24.Info [online], [dostęp: 23.08.2014], dostępny w Internecie: <http://www.glusi24.info> 
Szczególną rolę w aktywizowaniu kulturalnym ludzi niesłyszących odgrywa działająca od 2009 r. w Warszawie Fundacja Promocji Kultury Głuchych KOKON - organizacja pozarządowa, związana organizacyjnie z Instytutem Polskiego Języka Migowego. Jak czytamy na jej stronie internetowej, ma ona na celu:

\section{[...] promocje wszystkich zagadnień zwiazanych z Gtuchymi i ich kultura na terenie} Polski [...] powstata, by wesprzé́ polska spoteczność Gtuchych w jej walce o status spoteczny i uznanie jej praw. Uważamy, że u podstaw tej kultury leży Polski Jezzyk Migowy, używany codziennie przez ponad 100 tysięcy Polaków. Chcemy wspierać różnorodne dziatania kulturalne i spoteczne Gtuchych, prezentując spoteczeństwu bogactwo naszej kultury, a przy okazji przyczyniając się do zwalczania btędnych stereotypów na jej temat (Fundacja Promocji... [online]).

Menu witryny KOKON-u to: Strona startowa, O nas, Galeria, Twórczośc, Czytelnie, Kontakt, Deaf talent, ale zawartość dwóch linków jest dopiero w przygotowaniu. Dokładniej: dział Twórczość będzie - zgodnie z zapowiedzią, obejmować filmy migane przez Głuchych, w podziałach: historia, opowiadania, poezja i piosenki. $\mathrm{Na}$ opracowanie czeka też dział Czytelnie, o którym na razie brak bliższych informacji. Można się jednak spodziewać, że po przygotowaniu tych działów, niesłyszący będą mieli okazję do szerszej prezentacji własnych dokonań w języku migowym oraz dostępu do specyficznie odbieranej literatury, która znajdzie się w Czytelni. Niezależnie jednak od tego, już teraz społeczność Głuchych, głównie młodych internautów, może oglądać galerię zdjęć z ważnych dla nich wydarzeń, dowiadywać się o nowościach $\mathrm{z}$ ich własnego środowiska i spoza niego, obserwować, która z niesłyszących dziewcząt ma szanse zostać Miss Deaf Poland oraz którzy z nich zabłysną jako osoby o wyjątkowym talencie. Mogą zatem - dzięki multimedialnym formom KOKON-u - uczestniczyć w takich formach kultury popularnej i rozrywki, w jakich uczestniczą ich słyszący rówieśnicy. Warto dodać, że np. w 2013 r. wyborom Miss Głuchych w Teatrze Palladium, współorganizowanej z ONSI, towarzyszył spektakl „Cień Historii Głuchych”, stanowiący połączenie teatru cieni ze slajdami oraz artystyczną pantomimą. Były również występy poetyckie z PJM, które trafiły także na Fanpage artystów na Facebooku (Tamże 2014 [online]).

Fundacja KOKON kierowana jest przede wszystkim do nastolatków i młodych dorosłych (starsi stosunkowo rzadko posługują się technologiami informatycznymi i skodyfikowanym PJM). Przy niej także zaistniał Klub KOKO, obliczony na niesłyszące maluchy i ich - młodych przecież - rodziców, chociaż mogą tam bywać i korzystać z bogatej oferty również dzieci słyszące. Informacje o Klubie znajdują się na jego bardzo atrakcyjnej multimedialnie witrynie (Klub Koko [online]), dostępnej również przez adres www.migowy.pl oraz na jego stronie „fejsbukowej” (Koko Klub [online]). 


\section{Il. 9. Fundacja Promocji Kultury Głuchych KOKON, rzut strony}

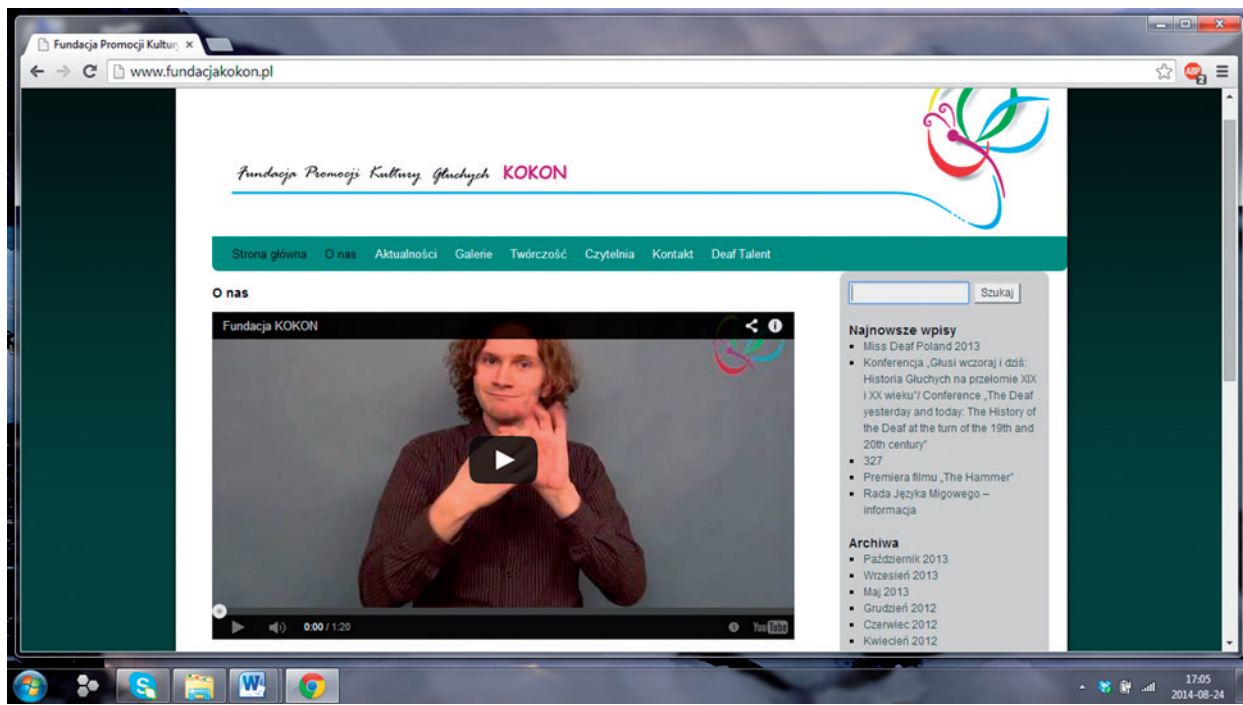

Źródło: Fundacja Promocji Kultury Gtuchych KOKON [online], [dostęp: 22.08.2014], dostępny w Internecie: <http://www.fundacjakokon.pl>

Już dotychczasowe wywody dowiodły, że dzięki rozwojowi technologii informacyjnych, które pozwoliły na tworzenie dostępnych w sieci różnorodnych form multimedialnych, młode generacje Głuchych mogą uczestniczyć w życiu kulturalnym oraz tworzeniu własnej kultury, nie tylko popularnej, ale i kultury określanej mianem wysokiej, do czego można je przygotowywać od wczesnych lat życia. Nic więc dziwnego, że odbywają się ich spotkania z poezją - nie tylko jako dodatek do imprez typu wybory miss, ale również w postaci festiwali. Tutaj na uwagę zasługuje Festiwal poezji miganej w Krakowie, który zaistniał głównie dzięki Między Uszami - Krakowskiej Fundacji Rozwoju Edukacji Niesłyszących im. Marka Mazurka. Zanim jednak przedstawiony zostanie sam festiwal, kilka zdań o Fundacji.

Jak czytamy na jej stronie internetowej, działalność Fundacji skoncentrowana jest na programach edukacyjnych dla dzieci i młodzieży niesłyszącej. Większość jej projektów ma charakter multimedialny, a pomoce edukacyjne stworzone w ramach ich projektów są udostępniane online w Internecie, za darmo na licencji Creative Commons BY. Najczęściej są to filmy z lektorem języka migowego. Fundacja tworzy także skrypty i pomoce dydaktyczne dla nauczycieli pracujących z niesłyszącymi. Efektem tych projektów są także prace plastyczne, grafiki i fotografie. Integralnym elementem każdego projektu Fundacji jest promocja kultury Głuchych (Między Uszami [online]). 
Jedno z niezwykle ciekawych działań fundacji to Czytanie jest fajne - projekt związany z rozwijaniem czytelnictwa dzieci i nastolatków. Dzięki niemu niesłyszący uczniowie mogą poznać wybrane lektury z klasyki i/lub kanonu literatury dziecięcej, w nagraniach w języku migowym.

\section{Il. 10. Czytanie jest fajne!}

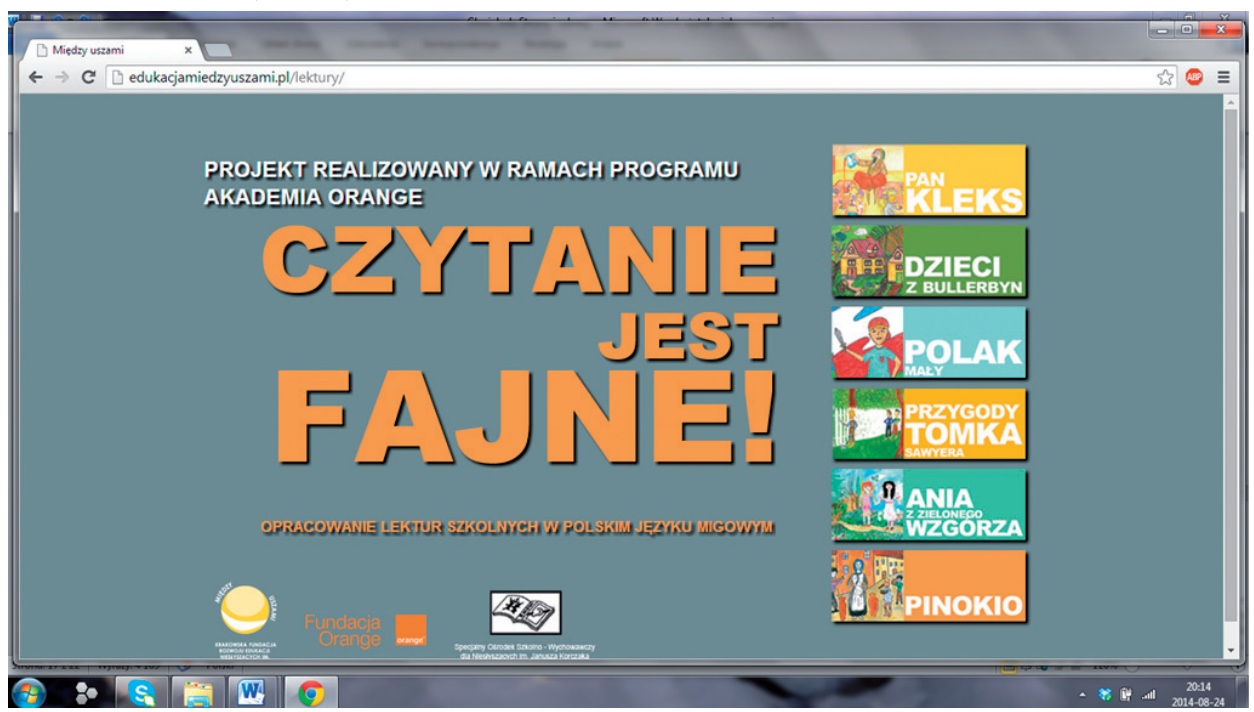

Źródło: Czytanie jest fajne [online], [dostęp: 24.08.2014], dostępny w Internecie: <http://www. edukacjamiedzyuszami.pl/lektury/>

Między Uszami troszczy się nie tylko o młodszych uczniów, ale przywiązuje dużą wagę do rozwijania zamiłowań literackich młodzieży i kształtowania jej wrażliwości poetyckiej. Służy temu m.in. wspomniany już wcześniej Festiwal poezji miganej. W czerwcu 2014 r. w Krakowie odbyła się jego pierwsza ogólnokrajowa edycja, w ramach projektu „Nie Bądź Głuchy na Kulturę”, realizowanego przez opisywaną fundację oraz partnera - firmę Far Beyond Business. Projekt zakłada aktywizację artystów głuchych oraz przybliżenie osobom słyszącym specyfiki języka migowego, którego najbardziej wyraźnym przykładem jest właśnie poezja migana (Kulturagluchych.pl [online]).

W ramach Festiwalu widzowie mieli okazję obejrzeć, poza prezentacjami poezji miganej, również różnorodne formy artystyczne przygotowane przez głuchych twórców, jak teatr, pantomima, performance, fotografia, malarstwo, grafika. Towarzyszyły temu wykłady w przystępnej formie objaśniające kulturę Głuchych, ponadto - inspirujące warsztaty artystyczne, całość zaś miała zapewnione tłuma- 
czenia w PJM. Nie trzeba chyba dodawać, że w Festiwalu uczestniczyli czynnie głównie młodzi artyści niesłyszący (Festiwal Poezji Miganej... [online]).

Wiadomo, że młodzież przepada za muzyką, a wymienianie się ulubionymi piosenkami stanowi jedną z istotnych form komunikacji pomiędzy nimi. Niesłyszący jednak, w potocznej opinii, nie mogą w żaden sposób odbierać muzyki, a także się nią cieszyć. Nic bardziej mylnego. Wprawdzie specyficzne sposoby słyszenia muzyki wymagałyby odrębnego omówienia, tutaj warto przedstawić Warsztaty muzyczne, które prowadzone są na Migiem na Majka, w ramach szczecińskiej TRAFO - Trafostacji sztuki (TRAFO [online]).

Warsztaty kierowane są głównie do młodzieży i młodych dorosłych. Jeden seans trwa 2 godziny, a liczebność grupy uczestników nie może przekraczać 8-12 osób. Organizatorzy wyjaśniają przy tym, że:

[...] muzyka to dziedzina tak rozlegta i wielowymiarowa, że potrafi uruchomić nasza wyobraźnię i emocje nie tylko poprzez zmyst stuchu, ale również za pośrednictwem catego ciata, poczucia rytmu i wspólnego transu, radości ruchu i muzykowania, które zawiera w sobie idee rytmu, pulsu, wspólnoty i medytacji. Istnieją również takie gatunki muzyczne, które są niemal w catości ztożone z elementów w petni dostępnych osobom z ubytkiem stuchu (Migiem na Majka [online]).

Migiem na Majka powstał jako integracyjny projekt muzyczny, na który składają się dwa programy warsztatowe. Mają one umożliwić osobom niesłyszącym i niedosłyszącym poznanie różnych gatunków muzycznych. Składają się z kilku uzupełniających elementów: teorii muzyki, podstaw rytmiki, warsztatów muzycznych w gatunkach samby ulicznej, gamelanu i hip-hopu oraz finałowego projektu koncertowego, z wykorzystaniem choreografii, multimediów i profesjonalnych środków scenicznych, adresowany jednocześnie do odbiorcy słyszącego i środowiska głuchych. Artystycznie ma być to komercyjny materiał nadający się na profesjonalną produkcję płytową lub trasę koncertową. Pokaz (pokazy) przygotowanego materiału mają mieć miejsce w przestrzeniach miejskich. Mogą mieć supporty albo być supportem lub stanowić niezależną formę wykonawczą. Mogą również mieć swoją kontynuację w postaci wydawnictwa DVD (Tamże).

Warsztaty na razie dopiero trwają i jeszcze nie doczekały się finału, ale bez wątpienia stanowią niezwykle ciekawy projekt, dzięki któremu młodzi ludzie z uszkodzonym słuchem mają szansę wejść w świat muzyki nie tylko jako odbiorcy, ale i jako artyści, współdziałający ze środowiskiem osób słyszących i nawiązujący z nimi kontakt na równych prawach.

Innym niezwykłym projektem, wprowadzającym młodych ludzi z niedosłuchem lub głuchotą w świat muzyki słuchanej przez ich rówieśników, są Oczy muzyki. 


\section{Il. 11. Oczy muzyki, rzut strony}

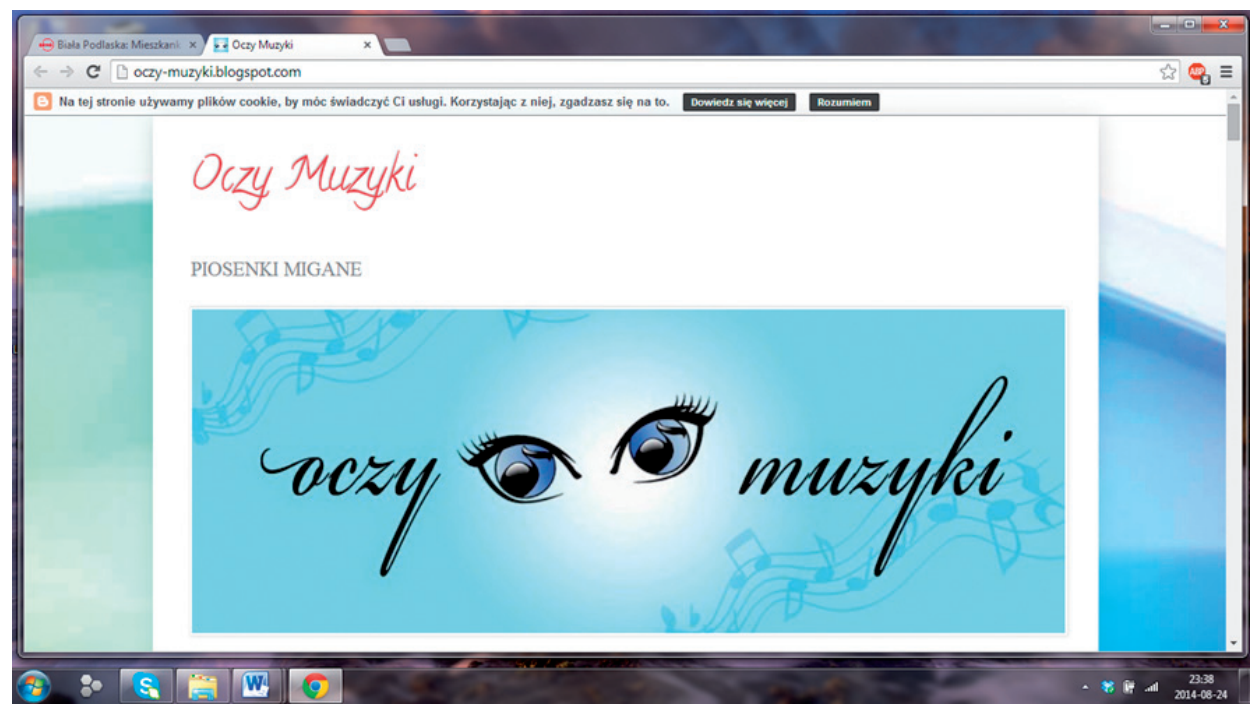

Źródło: Oczy muzyki [online], [dostęp: 24.08.2014], dostępny w Internecie: <http://oczy-muzyki.blogspot.com/>

Realizacja tego projektu nie byłaby możliwa bez zaangażowania osób, które z równym powodzeniem żyją w świecie dźwięków, jak w świecie ciszy. Do nich - w tym projekcie - należy jego inicjatorka i autorka - Agnieszka Bajbak z Białej Podlaskiej. Jest ona wykładowcą i tłumaczem języka migowego. W roku 2012 zaczęła prowadzić stronę internetową Oczy Muzyki, na której zamieszczała utwory polskich wykonawców przetłumaczone na migi. Tak sama mówi w jednym z wywiadów:

Moi niestyszacy znajomi i studenci domagali sie, abym ttumaczyta im teksty utworów [...] Na Zachodzie to jest normalne, to jest standard. Osoby niestyszace maja 24 godziny na dobę napisy, maja ttumacza $w$ telewizji, natomiast $w$ Polsce traktowane jest to wybiórczo. Ktoś decyduje za nich, czego moga stuchać, co ogladać, do jakich informacji moga mieć dostęp. To jest w pewnym sensie tamanie ich prawa. Żyjemy przecież w państwie demokratycznym, gdzie każdy może mieć dostęp do wszystkiego, a im się ten dostęp ogranicza, dlatego postanowitam, że będę ttumaczyta piosenki (Poczuć i zobaczyć muzykę [online]).

Niezwykle energiczna, pozyskała do współpracy wielu współczesnych polskich piosenkarzy i zespoły (Big Cyc, Czarno-Czarni, Enej, Liber, Zakopower, T. Love, Elektryczne Gitary, Stanisław Sojka, Farba, Natalia Kukulska, Manufaktura). 
W pięknych teledyskach, realizowanych w ciekawych miejscach, poza nią, w charakterze osób migających słowa piosenek występują czasem jej studentki, o samym projekcie zaś nie tylko pisała prasa, ale powstały programy z udziałem Agnieszki Bajbak, gdzie w niezwykle atrakcyjny i ciekawy sposób opowiadała o swoim projekcie, ilustrując wywody fragmentami miganych piosenek. Programy te, wyemitowane w Faktach TVP oraz w TVP Sport, obejrzeć można również na You Tube, np. Oczy Muzyki w Faktach TVP ([online]), czy Oczy Muzyki w magazynie „Petnosprawni” w TVP Sport ([online]).

Tę część rozważań wypada zakończyć stwierdzeniem wyartykułowanym przez Agnieszkę Bajbak: muzykę można zobaczyć poprzez emocje, ruch, światła czy drgania. Trudno się z tym nie zgodzić. Jednocześnie należy podkreślić, że jej wspaniałe działania, obliczone na specyficzne możliwości odbiorcze osób głuchych, posługujących się językiem migowym, dały im również dostęp do szeroko pojmowanej kultury muzycznej i jej współtworzenia.

\section{Podsumowanie i wnioski}

Przedstawione w artykule różnego rodzaju formy multimedialne, zanalizowane pod kątem ich przydatności w komunikacji osób z uszkodzonym analizatorem słuchu i roli, jaką mogą pełnić w różnych sferach ich życia, powstały pod wpływem rozwoju technologii informacyjnych, a zwłaszcza komputerów z właściwym oprogramowaniem i dostępem do sieci. Jest ich wiele, a spora ich część obliczona została na małych lub młodych użytkowników. Oni właśnie mogą skorzystać z nich najbardziej: zarówno wtedy, gdy są osobami niedosłyszącymi, jak głuchymi od urodzenia. Oczywiście, potrzeby każdej z tych grup są nieco inne, stąd też powstają zróżnicowane odmiany multimediów, ale nie ulega wątpliwości, że otwierają one nowe możliwości.

Dzieciom z niedosłuchem pozwalają na poznawanie i doskonalenie języka fonicznego, co ułatwia im swobodniejsze porozumiewanie się ze słyszącymi rówieśnikami, przygotowując zarazem do samodzielnego czytania i czytelnictwa, a to z kolei zwiększa ich szanse edukacyjne i dostęp do informacji pisanej oraz wprowadza w świat literatury. Natomiast młodym niesłyszącym multimedia umożliwiają rozwijanie zunifikowanego języka migowego (w czym ogromną rolę odgrywają jego słowniki), dostęp do informacji w tym języku poprzez portale multimedialne, które oferują również możliwości dyskusji na różnego rodzaju forach, przygotowują do tworzenia i korzystania z nowych technologii, a najmłodszych z nich wprowadzają w świat bajek, baśni i lektur szkolnych w ich macierzystym języku.

Nie można pominąć roli rozmaitych form multimedialnych w dostępie do kultury i sztuki, a nawet muzyki. Niwelowane są w ten sposób różnice pomiędzy słyszącymi a niesłyszącymi rówieśnikami, tym bardziej, że ci drudzy również mają 
możliwość rozwijania własnej twórczości, dzielenia się nią, odnoszenia sukcesów artystycznych. Niebagatelne znaczenie mają przy tym portale tworzone przez i dla osób z uszkodzonym słuchem, które - jak już sygnalizowano - obejmują wszystkie sfery życia i upowszechniają niezwykłą kulturę społeczności Głuchych, jednocześnie integrując całe środowisko.

Wydawałoby się zatem, że szanse pomiędzy „mieszkańcami świata ciszy” a słyszącymi zaczynają się wyrównywać. Jednakże tak nie jest, o czym świadczą liczne doniesienia samych Głuchych, zamieszczane na ich portalach, z których dowiadujemy się o dziesiątkach czy nawet setkach przykładów wskazujących na ich dyskryminację. Nie można również zapominać o tym, że z tych portali korzystają głównie ludzie młodzi, starsze pokolenie ani nie umie, ani nie chce po nich serfować. Ponadto, większość fundacji oraz stowarzyszeń promujących kulturę Głuchych i zabiegających o ich prawa, działa wyłącznie na terenach wielkich miast, a nowe technologie, w tym programy multimedialne, są bardzo drogie, stąd też zasięg ich oddziaływania nie jest zbyt szeroki. A zatem jest jeszcze wiele do zrobienia. Nie zmienia to faktu, że multimedia wśród e-generacji pełnią liczne, niezwykle istotne funkcje: dydaktyczne, edukacyjne, kompensacyjne i integracyjne, służąc także rozrywce oraz wyzwalając kreatywność. Oby stale gościły wśród dzieci i młodzieży z uszkodzonym słuchem, z których przecież wyrosną dorośli, znacznie lepiej przygotowani do życia w rzeczywistości cyfrowej oraz w świecie dźwięków.

\section{Bibliografia}

Alfabet. Zabawy literami i gtoskami. Ćwiczenia percepcji stuchowej [online], [dostęp: 20.08.2014], dostępny w Internecie: <http://www.otostrona.pl/terapialogopedyczna/index.php?p=1_7_Multimedia>

Bajki nie tylko dla dzieci gtuchych [w:] Facebook [online], [dostęp: 24.08.2014], dostępny w Internecie: <https://pl-pl.facebook.com/bajki>

Czytanie jest fajne [online], [dostęp: 24.08.2014], dostępny w Internecie: <http:// www.edukacjamiedzyuszami.pl/lektury/>

Deaf Poland. Forum dyskusyjne osób z wadą stuchu [online], [dostęp: 21.08.2014], dostępny w Internecie: <http://www.deaf.pl>

eduSensus Logopedia. Mówiące obrazki 2.0 [online], [dostęp: 21.08.2014], dostępny w Internecie: <http://www.3kropki.pl/p/4/2/0/edusensus_logopedia_mowiace_obrazki.php>

Festiwal Poezji Miganej w Krakowie [online], [dostęp: 24.08.2014], dostępny w Internecie: <http://www.mik.krakow.pl/2014/04/30/festiwal-poezji-miganej-w-krakow> 
Folkman A. (2014), Zobacz bajki dla dzieci, które nie styszq [online], [dostęp: 20.08.2014], dostępny w Internecie: <http://www.gs24.pl/apps/pbcs.dll/article?AID=/20110305/SZCZECIN/502397541>

Fundacja KOKON. Aktualności [online], [dostęp: 24.08.2014], dostępny w Internecie: <http://www.fundacjakokon.pl/aktualnosci/>

Fundacja Promocji Kultury Gtuchych KOKON [online], [dostęp: 21.08.2014], dostępny w Internecie: <http://www.fundacjaKOKON.pl>

Glusi24.info [online], [dostęp: 23.08.2014], dostępny w Internecie: <http://www. glusi24.info/>

Glusi.pl [online], [dostęp: 20.08.2014], dostępny w Internecie: <http://www.glusi.pl/content/o-nas>

Klub Koko [online], [dostęp: 20. 08.2014], dostępny w Internecie: <http://www. klubkoko.pl>

Koko Klub [online], [dostęp: 20.08.2014], dostępny w Internecie: <https://www. facebook.com/KlubKoko/info?ref=page_internal>

Komputerowy Stownik Języka Migowego [online], [dostęp: 21.08.2014], dostępny w Internecie: <http://www.pcworld.pl/news/76581/Komputerowy.Slownik.Jezyka.Migowego.html>

Kulturagluchych.pl [online], dostęp: 24.08.2014], dostępny w Internecie: <http:// www.kulturagluchych.pl/>

Logo-gry 2.0 [online], [dostęp: 20.08.2014], dostępny w Internecie: <http://www. ydp.com.pl/logo-gry-\%E2\%80\%93-logopedyczne-gry-i-zabawy-dla-dzieci>

Logopedia [online], [dostęp: 21.08.2014], dostępny w Internecie: <http://www. dobreprogramy.pl/Logopedia,Program,Windows, 11665.html>

Między Uszami [online], [dostęp: 24.08.2014], dostępny w Internecie: <http:// www.miedzyuszami.pl>

Migam [online], [dostęp: 22.08.2014], dostępny w Internecie: <http://www.migam.pl/o_nas>

Migiem na Majka [online], [dostęp: 24.08.2014], dostępny w Internecie: <http:// www.trafo.org/index/site/id/160>

Mówiące Obrazki - Program komputerowy do terapii dzieci... [online], [dostęp: 21.08.2014], dostępny w Internecie: <http://www.eduksiegarnia.pl/mowiace-obrazki-program-komputerowy-terapii-...>

Multimedia - podstawowe pojęcia [online], [dostęp: 30.07.2014], dostępny w Internecie: <http://www.edukacja.edux.pl/p-803-multimedia-podstawowe-pojecia.php>

Nasze rozpoznawanie mowy: SkryBot.pl [online], [dostęp: 25.08.2014], dostępny w Internecie: <http://skrybot.pl/skrybot-pl-nasze-rozpoznawanie-mowy/>

Oczy Muzyki [online], [dostęp: 24.08.2014], dostępny w Internecie: <http:// oczy-muzyki.blogspot.com/> 
Oczy Muzyki w Faktach TVP [online], [dostęp: 25.08.2014], dostępny w Internecie: <https://www.youtube.com/watch?v=kUU1VkOKZHg>

Oczy Muzyki w magazynie "Petnosprawni” w TVP Sport [online], [dostęp: 25.08.2014], dostępny w Internecie: <https://www.youtube.com/watch?v=3QT7HjqXe-A>

Organizacja Niestyszacych - Stabostyszacych Internautów (ONSI) [online], [dostęp: 18.08.2014], dostępny w Internecie: <http://www.onsi.pl>

Platforma Toker [online], [dostęp: 25.08.2014], dostępny w Internecie: <http:// www.toker.com.pl/cwiczenia-logopedyczne-dla-dzieci/>

Poczuć i zobaczyć muzykę [online], [dostęp: 24.08.2014,] dostępny w Internecie: <http://podlasie24.pl//wiadomosci/biala-podlaska/poczuc-i-zobaczyc-muzyke-1049e.html>

Sak M. (oprac.) (2012), Cztery kroki. Wsparcie osób niestyszących na rynku II, Warszawa, Państwowy Fundusz Rehabilitacji Osób Niepełnosprawnych, ISBN 978-83-908631-6-2

Stownik Polskiego Języka Migowego [online], [dostęp: 20.08.2014], dostępny w Internecie: <http://www.spjm.webd.pl>

Spoteczność Gtuchych [w:] Facebook [online], [dostęp: 22.08.2014], dostępny w Internecie: <http://www.facebook.com/GlusiPl>

Stowarzyszenie Gtuchy Świat [online], [dostęp: 30.12.2014], dostępny w Internecie: <http://gluchyswiat.pl/>

TRAFO [online], [dostęp: 19.08.2014], dostępny w Internecie: <http://www.trafo.org/index/site/id/160>

Ustawa o jezzkku migowym i innych środkach komunikowania się, Dz. U. 2011, nr 209, poz. 1243

Woźniczka-Paruzel B. (2014), Komunikacja wizualno-przestrzenna osób niestyszqcych a świat książki i informacji [w:] Głowacka E., Kowalska M., Krysiński P. (red.), Wspótczesne oblicza komunikacji i informacji. Problemy, badania, hipotezy, Toruń, Wydaw. Naukowe Uniwersytetu Mikołaja Kopernika, s. 349-368

Woźniczka-Paruzel B. (2013), Sign Writting jako droga do aktywizacji czytelniczej dzieci niestyszacych (o nowych możliwościach języka migowego - dla bibliotekarzy [w:] Antczak M., Brzuska-Kępa A., Walczak-Niewiadomska A. (red. nauk.), Kultura czytelnicza dzieci i mtodzieży poczattu XXI wieku. Szkice bibliologiczne, Łódź, Wydaw. Uniwersytetu Łódzkiego, 2013, s. 159-180

Zapraszamy: ww.glusi.com.pl [online], [dostęp: 22.08.2014], dostępny w Internecie: $<$ http://www.youtube.com/watch?v=GF428kcar_I>

Zobaczyć ciszę [online], [dostęp: 23.08.2014], dostępny w Internecie: <https:// www.youtube.com/channel/UC6-d08FSsqdrRJtnGoABDkw>

Zobaczyć ciszę-zapowiedź [online], [dostęp: 21.08.2014], dostępny w Internecie: <http://youtu.be/S4lCTPhi7e4> 


\begin{abstract}
Abstrakt
Artykuł poświęcony jest multimediom i roli, jaką obecnie odgrywają nie tylko w komunikacji, ale również $\mathrm{w}$ dostępie do informacji i w praktykach czytelniczych osób głuchych od urodzenia, dla których językiem macierzystym jest język migowy. Po wstępnych wyjaśnieniach dotyczących multimediów, przedstawione są te ich rodzaje, które mają szczególne znaczenie dla ludzi młodych, nazywanych „e-tubylcami” lub „e-generacją”. Zdecydowana ich większość dostępna jest dzięki rozwojowi technologii informacyjnych, a zwłaszcza Internetu. Nie bez znaczenia są również specjalne programy komputerowe, tworzone dla osób niesłyszących. Niektóre z nich pozwalają na naukę i doskonalenie języka migowego (np. komputerowy słownik języka migowego), na usprawnianie języka fonicznego (np. Logo - gry), czy przekształcanie (transkrybowanie) mowy na tekst (SkryBot). Inne ułatwiają dostęp do informacji w języku migowym, korzystanie z portali internetowych i uczestnictwo w specyficznych praktykach czytelniczych, co jest zwłaszcza istotne dla dzieci i młodzieży. Multimedia pełnią liczne funkcje: kompensacyjne, dydaktyczne, edukacyjne i integracyjne, służąc także rozrywce i wyzwalają kreatywność, dlatego też warte są uwagi badawczej.
\end{abstract}

\begin{abstract}
The article is dedicated to multimedia and the role they currently play not only in communication, but also in access to information and reading practice for people deaf from birth whose native language is sign language. After some introductory explanations concerning the media, those types that have particular relevance to young people called "e-natives" or "e-generation", are presented. The vast majority of them is available thanks to the development of information technologies, especially the Internet. Special computer programs created for the people with hearing impairment are also quite significant. Some of them allow learning and improvement in sign language (e.g. computer-based sign language dictionary), improvement in phonic language (e.g. Logo-games) or converting speech to text (SkryBot). Others facilitate access to information in sign language, the use of Websites and participation in specific reading practice, which is especially important for children and adolescents. Multimedia serve numerous functions: teaching, educational, compensating, and integrative as well as those serving entertainment and liberating creativity. Therefore, they are worth paying good attention.
\end{abstract}

